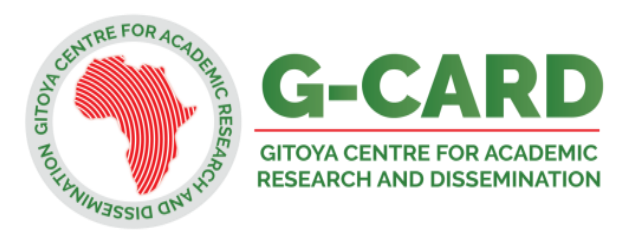

\title{
Lived Experience of Literacy Coaches in the Technology-based Classrooms to improve Students' Literacy among Non-traditional High Schools in Jamaica
}

\author{
Claudine Bent-Cunningham and Daniel Allida, PhD \\ Northern Caribbean University, Mandeville, Jamaica \\ Corresponding Author: claudine.cunninghampml@yahoo.com
}

\begin{abstract}
Purpose of the study: This research sought to investigate the extent to which the Alternative Pathways to Secondary Education (APSE) program implemented in Jamaica to address deficits in literacy has worked in addressing the apparent achievement gap which is so evident among students in Non- traditional High schools. The research also sought to determine what kind of support is needed for Literacy coaches and literacy teachers to maximize these students' learning opportunities. This qualitative phenomenological study employed the thematic text analysis approach. This study selected pathway/literacy coaches based on the Secondary school/ Non-traditional high schools selected for the study. The research attempted to investigate the challenges that these seven coaches experienced in integrating technology in their guiding of the Apse program in improving students learning challenges in Literacy. The research found that students in the Apse program were mainly at-risk children who came from low-income homes and who were predominantly boys who had learning difficulties. It was concluded that more technological resources were needed in Nontraditional schools. The Alternative Pathways to Secondary Education (APSE) program has a high accountability measure which helped to improve students' performance in Literacy. The researcher recommends increased personnel in guidance departments to stem behavioral issues, policy development for increased technological integration in schools, and more accountability measures for students.
\end{abstract}

Keywords: Literacy coaches, apse curriculum, technology classroom, non-traditional schools

\section{Introduction}

Literacy and numeracy are key aspects for achieving the 2030 Agenda for Sustainable Development. However, alarming statistics reveal that 757 million adults, including 115 million youth are unable to read or construct a simple sentence (UNESCO, 2019).

In response to this problem, the government of Jamaica has been striving to improve literacy of citizens through its Vision 2030 initiate. However, a study conducted by the Planning Institute of Jamaica (2009) Education) postulates that $35 \%$ of primary school leavers are illiterate and only $26 \%$ of secondary school graduates had the requisite qualifications for meaningful employment or matriculation to college. In the context of Jamaica, the educational reformers introduced several curricula in a quick succession: Science, Technology, Engineering and Mathematics (STEM) in 2014,
Science, Technology, Engineering, Arts, and Mathematics (STEAM) between 2015 and 2016, and in 2017 with the more recent change at the helm of the education sector, the Alternative Pathways to Secondary Education (APSE) curriculum.

The STEM curriculum is an integration of the four disciplines: Science, Technology, Engineering and Mathematics in developing the higher order critical thinking skills and applying these to real life experiences. Conversations among the intellectual minds locally questioned the implementation of the STEM program and its ability to find relevance in the national thrusts towards a more prepared workforce and sustainable development goals in keeping with vision 2030 (Sweeney, 2019).

Other writers purport that the gap in the STEM program lies in the absence of the fine arts as well as an inculcation of writing and reading which is paramount to students being able to comprehend 
and explicate their experiences in the disciplines (Lewis, 2016).

This study propels further the current debate on achievement gap within the Jamaican education sector as highlighted in the article of Paulette Fereria regarding conversations on curriculum and students' achievement (Fereria, 2016). The study illuminates the characteristics of curriculum within the Jamaican context and its ability to meet the needs of Jamaican learners at the ninth-grade matriculating to the Secondary Schools. The study of Fereria further points to the need for teacher preparedness, teacher inputs, awareness and understanding of the APSE curriculum, as well as the 'amalgamation of curriculum and teaching for enhancing learner outcome and bridging the achievement gap in the Jamaican classroom. This study sought to fill the gap.

The Alternative Pathway to Secondary Education Program (APSE) has as its theoretical framework the ideology of the Problem Based Curriculum which was also the thrust for education in Jamaica in the 1960's for Comprehensive and Technical High Schools within the Secondary education school system (APSE Curriculum, 2017). An historical overview of the problem-based approach can be found in the study of Savery (2006) which postulates that the ideology began with the investigations of philosophers like Confucius, Sophocles and Plato who were advocates for inquiry and critical thinking. The researcher posits that the philosophy was further propelled by Dewey then by Kilpatrick (1925) cited in Korkmaz and Kalayci (2019) and that it should be used mainly in the vocational and secondary educational system. It is defined by the researcher as an approach which has the learner at its core. It enables the learner to "conduct research, integrate theory and practice, apply knowledge and skills to solve problems within the real world" (p.7). Savery (2006) borrows the ideas of Barrows (nd) to give an overview of problem-based learning: 1. Students must be responsible for their learning. 2 . Problem simulation must be un-structured and foster free inquiry. 3. It should have learning integration from a wide array of subjects. 4. It should foster collaboration 5 . It should have selfdirected learning for problem solving 6 . It should have analysis of knowledge to determine what has been grasped 7 . It should consist of self and peer assessment 8 . It must be valued in the real world 9 . Its assessment must be aligned with the goals of the problem-based curriculum and 10 . It must be pedagogically based.

The integration of the problem-based curriculum, amalgamated with advanced technological tools within the $21^{\text {st }}$ century, is a valuable combination for sustainable growth and development since students are sufficiently prepared to advance career paths in a fast changing globalized, digital space. It has a myriad of advantages including improvement in critical thinking skills and improvement in students' performance. There are however, opposing factors such as teacher's willingness to change from the traditional pedagogical styles (Bashith \& Amin, 2017). Change requires careful planning by implementers and curriculum designers in order to eliminate obstacles (Ghavifekr, Razak, Ghani, Ran, Meixi \& Tengyue, 2014).

The study was guided by the following research questions:

1. What are the experiences of literacy coaches in delivering and facilitating technology -based learning?

2. What are the characteristics of the technology-based classroom?

3. What is the level of accountability evident in the technology-based program for literacy improvement?

\section{Literature Review}

This part presents the literature review to throw more light in various concepts.

\section{Technology in the $21^{\text {st }}$ Century}

It is no surprise that technology has evolved and has ascended novel advances within the 21st century. These vast changes are an attempt to facilitate the marketability of individuals in a competitive, global digitized space referred to as 'industry 4.0'. Institutions have moved to upgrade the traditional presentation of technology within curricula to align with the expectations of the $21^{\text {st }}$ century career; as such, the 'vocational education' has been renamed 'career and technical education' and includes programs which are geared towards specialized skills, technology and job preparations (Venkatraman, DeSouza-Daw, \& Kaspi, 2018). Since the period of the late 1900's to the 2000, millennials' interaction with technologically advanced tools has changed the face of technology by moving the communication from speech to text through a multiplicity of modes such as internet, videos, audios, computer programming and most outstandingly, cell-phone use (Spires, Paul \&

8 East African Journal of Education and Social Sciences (EAJESS) 2(2)7-16 
Kerkhoff, 2017). With this new revolution in the technological space, students' technological capacity is of prime importance.

This idea is reiterated in the views of Kavalier and Flannigan (2006) who believe that this generation, also known as the e-generation, has sought to employ technology to connect and interact with a global society in a growing global economy far more than previous generations. The researchers extrapolate on the view that society today must be prepared for the expertise of this present generation regarding curriculum and instruction, and the delivery of content through the use of Information and Communication Technologies (ICTs) or Career and Technology Education (CTE). Institutions that have not implemented plans for sustained upgrade may find themselves being left behind, since technological upgrade through the ages is inevitable (Kavalier and Flannigan (2006). The study of Eshet (2004) has sparked debates about the modalities of digital literacy, while promulgating his own definition of the concept. According to him, there are five types of literacy: photo-visual, reproduction, branching, information and socio-emotional, all of which are vital for understanding the digital or technological literacy as a whole.

\section{Technology and the Classroom}

Although it is simply a catalyst to enhance what goes on in the teaching and learning environment, technological tools within the educational space continue to bring colossal changes which improve the teaching and learning process. Purdue University (2020) has outlined the way technology in the classroom has evolved throughout the epoch from the 'primitive years' of 'horn books' and 'paddles' to magic lanterns (now called projectors), then chalkboard and pencil by the 1900's. The teaching learning environment has benefitted from an influx of a myriad of technological tools which complement the delivery of content and improve performance among students at varying levels. Ivy (2017) has suggested the use of several technological tools which can be found in the typical classroom. Some of these are computer, which students can use to 'manage assignments, such as typing papers, creating presentations or making video slides. Other technological tools include laptops, tablets, smart boards and social media.

Irving (2006) discusses how technology has changed in the $21^{\text {st }}$ century science classrooms. The new technologies have contributed to major breakthroughs in the teaching of science and the field of science as a whole. In her discussion, the researcher demonstrates the effectiveness of technology. Today, schools in the United States have the mantra of ensuring that there is 'No Child Left Behind'. Both public and private schools are now creating a network of learners where teachers, students, and parents can interact on google classrooms, in an attempt to strengthen relationships between the macro and micro communities regarding curriculum, assessment and technology use (Iftakhar, 2016). Similarly, in fulfilling its mantra: 'Every child can learn, every child must learn', Jamaica has distributed 40,000 tablets to ensure that students have the opportunity to gain access to virtual classrooms in order to maximize the teaching and learning across subject areas (Angus, 2020).

\section{Teacher Preparedness for ICTs}

Teacher preparedness is a vital factor for a successful technology implementation in the $21^{\text {st }}$ century classrooms. The Department of Education (DOE) in the United States promulgated some basic requirements for quality assurance within the digital sphere in accordance with the USA Department of Education (2017). Since 2020, the plan has sought to improve its mantra to match current trends (USA Department of Education (2017). The Department of Education therefore outlined four guiding principles which will aid teachers in becoming effective in guiding and delivering technology-based instruction, these include:

1. Focusing on the active use of technology to enable learning and teaching through creation, production and problem solving.

2. Building sustainable, program-wide systems of professional learning for higher education instructors to strengthen and continually refresh their capacity to use technological tools to enable transformative teaching and learning.

3. Ensuring pre-service teachers' experiences with educational technology are programdeep and program-wide rather than one-off course separate.

4. Aligning efforts with research-based standards, frameworks and credentials recognized across the field. 
Studies which support teacher preparedness for technology-based instruction argue that teacher involvement in the process of technology integration within the curriculum may encourage their belief and effort about using technology to enhance their own pedagogical skills (Hennessy, Deaney \& Ruthven (2005), Gill and Delgarno, (2008); Ghavifekr and Rosdy (2015). When teachers are left out of the important phases of curriculum planning and technology integration, the need for change becomes retarded as factors which militate against the teacher's realities in the classroom are sometimes not taken into consideration which results in disharmony between classroom practices and curriculum expectations (Charalambas and Glass, 2007). In keeping with the world trends, teacher training institutions should upgrade their practice to aid educators to remain abreast with advancements in the digital society (Ruales, 2012).

\section{Challenges with ICTs and the Classroom}

Despite the progress of technological advancements in enhancing education in the Caribbean education system, some territories, according to Tondeur, Braak, Ertmer and Leftwich (2016) face challenges which obstruct the potential of technology to fully enhance students' performance in varied contexts and subject disciplines. These challenges include insufficient ICT utilization; lack of access to ICTs resulting in a digital divide; sustainability and scalability in ICTs use among educators; the effective application of technology among educators and discerning the technological tools that are correct within the specific learning context. The researchers state that challenges for developing countries are more colossal than challenges in developed countries. They further posit that some major issues with ICTs in developing countries include teacher quality, equity and efficiency, an argument which reiterates the views of Tondeur et al. (2016) and Gudmundsdottira and Hatlevikb (2018). For countries such as Jamaica, challenges with ICTs in the technology-based classroom have worsened since the COVID-19 pandemic which has resulted in educators appealing to the government to implement changes to the curriculum regarding technology integration (Hibbert, 2020; Mignott, 2020).

\section{Accountability and the Problem-Based Curriculum}

In order to determine if the education sector is efficiently serving the needs of its clients, there must be efficient and effective accountability measures. According to Brill, Grayson, Kuhn, and O'Donnell (2018), accountability in the practice of education can be defined as the mechanism implemented by a country's government for holding educational institutions accountable for the delivery of high-quality education. Matthews (2018) calls for greater accountability within the Jamaican education system. He opines that the current bodies which are responsible for evaluating schools are inadequate and are given very little autonomy to make changes based on their findings. Hence, bodies such as the National Educational Inspectorate (NEI) has the power to evaluate schools and make recommendations, but they do not have the power to ignite change. The Minister of Education has assured the populous that the newly implemented Alternate Pathways to Secondary Education (APSE) program has a thorough accountability framework which assures quality education for all students on its varied pathway programs so that all students may learn and succeed (Angus, 2016). For Secondary Pathways 1,11 , and 111 , the exit examinations for primary schools will determine placement and intervention into secondary schools. Once students are placed in secondary schools or non-traditional high schools, literacy coaches and literacy specialists collaborate in planning lessons, intervention measures and alternative forms of assessment to procure positive and increased student outcome (APSE and CAP, nd.)

\section{Research Methodology}

This study employed the phenomenology approach. The qualitative heuristic approach is ideal for this study because it allows the literature to be developed from the stories of the daily experiences of educators as they deliver content across disciplines employing technology (Moustakas, 1990). The researcher also utilized the thematic text analysis approach to analyze the data (Kuckartz, 2014).

\section{Population and Sampling}

This study used purposive sampling (Creswell, 2008) whereby ten participants were selected. It selected seven pathway /literacy coaches based on the Secondary school/ Non- traditional high schools and for the purpose of triangulation, the study also included two supervisors of literacy coaches and one literacy teacher (Res. 1, 2 \& 3 respectively). The study sought to find out how these seven coaches (Res.4 to 10) integrate technology in their guiding of teaching strategies to improve learning. It also sought to ascertain some challenges they 
encountered in the varied disciplines and accountability measures taken.

\section{Data Collection}

The data collection method utilized for this study was interview. The semi-structured approach to questioning was utilized so that the respondents would be free to tell their stories the way they wanted. The interviews were video recorded and transcriptions were made. The semi- structured questions for the interview were reviewed by the Institutional Review Board and adjustments were made.

\section{Findings of the Study}

This section presents the results of the study and delineates a discussion based on research questions which guided the study.

Research Question 1: What are the experiences of literacy coaches in delivering and facilitating technology -based learning in the Apse program?

Literacy coaches stated that they found it difficult to adequately fulfil the requirements of the APSE program because teachers did not receive specialist training to address some students' grave issues which act as hindrances to effective learning. Even though the coaches received adequate support in the form of training in order to meet the program requirements, the support became inadequate regarding helping coaches to meet the needs of students.

At Risk Students: Most Non - traditional High Schools are recipients of students who performed below the required average in their primary school grade six exit examination and who were reading below the required reading levels for their age. There are those persons in the Jamaican society who conclude that Non-traditional High Schools are for students who are low achievers. While it is a fact that a high percentage of Non-traditional High School students need learning support, there are those students who are high achievers who successfully matriculate into their colleges of choice (Hunter, 2014).

The study focused on Non-traditional High Schools because these schools are fairly new and many of them do not benefit holistically from alumni groups, private sector sponsorship, neither do many of these schools have strong parental support. Majority of the non- traditional high schools are solely dependent on the government for full financial support. Non- traditional high schools which are upgraded high schools in Jamaica have a high percentage of at-risk students. According to Crossfield and Bourne (2018) at risk students are those students who are in danger of dropping out of school. They exhibit certain traits such as continued academic failure, vast age differences than their peers, emotional and behavioural problems and increased disinterest in schooling. In addition, the authors postulate that the highest percentage of the at-risk children belong to families at the lower socioeconomic strata. Res. 2 - 10 describe this as one of the major characteristics of students who are placed in the APSE program. Many of these students are at risk students who live in low- income communities. The study demonstrates that a high percentage of at-risk students on alternative pathways 11 and 111 are predominantly boys.

\begin{tabular}{|c|c|}
\hline At Risk Students & In Vivo Coding \\
\hline Res. 2 ....................... & .. Learning Difficulties \\
\hline Res. 3....................... & ...Learning Challenges \\
\hline Res. $4 \ldots \ldots \ldots \ldots \ldots \ldots . . . . . .$. & ...Disruptive Students \\
\hline Res. 5..................... & ....Low Performance \\
\hline 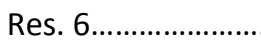 & ....Social Challenges \\
\hline 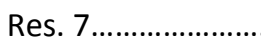 & ....Low Performance \\
\hline Res. 8..................... & ....Need Learning Support \\
\hline 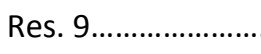 & ....Girls who have learning challenges \\
\hline Res.10.................... & ....Low Socio - Economic Background \\
\hline
\end{tabular}

Fig. 1 Responses of coaches showing their experiences with at risk students in APSE approach

At- risk students have learning challenges and are sometimes disruptive. They also have grave social challenges and they display low academic performance (Larose \& Tarabulsy, 2014). From figure 1 , teachers reported that at- risk students have learning challenges which resulted in performing poorly. Some at- risk students are disruptive and display poor social etiquette which most times negatively influence the learning space. Both girls and boys form part of the at-risk groups 
with a larger representation for boys. In brief, at risk students are those who are in dire need of learning support. A combination of this plethora of issues makes it difficult for APSE coaches and Literacy teachers to facilitate at- risk students sufficiently and effectively.

Adequate Support: In response to research question 1, the chief supervisor explained that, the 'Ministry initially supplied technological tools to schools then changed to giving money so schools could purchase their own equipment' (Res. 1). The Supervisor at the local level added that, 'Workshop is held by the Ministry and APSE coaches receive training' (Res. 2). Coaches also concurred that they receive continuous training in best practices so that they are adequately able to support the teaching and learning (Res. 3-10). While APSE coaches experienced continuous training to facilitate the approach, the training did not account for many other educational and social issues which largely exist among many of the student cohorts across the different Non- Traditional High Schools. It is in this regard that coaches felt that they experienced inadequate support in carrying out their task.

Inadequate Support: In response to research question 1 , some coaches admit that some problems they encountered are that some students are considerably disruptive and demonstrate ongoing social challenges. According to the literacy teacher, 'students display high levels of disinterest' (Res 3); The local supervisor and other respondents admitted that many of the students belong to lowincome homes where one parent may be working a menial job to support several household members (Res. 2-10). Res. 4 concurs that students suffered from low motivation, and many are frequently absent from school. Res 6. admitted that 'classes are also over-crowded', which makes the environment less favorable and more viable in evoking the issues that coaches, supervisors and literacy teachers have expressed. All respondents stated that there was some help from school authorities, but the issues persisted (Res 2-10). This leads to high frustration levels among educators and probably teacher burn out. It may also be the reason that some coaches are 'not receiving the full corporation of the entire teaching body in employing the APSE approach within their lesson delivery' (Res. 8). When the responses of each participant are combined regarding gender, $75-80$ $\%$ of students on pathways are predominantly boys with only a small percentage of girls (Res.2-10). In this view it could be derived that majority of the concerns described are related to students who are predominantly male which can result in grim repercussions within the macro- community (Morgan, 2012).

Research Question 2: What are the characteristics of the technology-based classroom at your school?

The APSE approach requires students to engage with the technological-based classroom. The Ministry of Education has allocated funds to support the program in this regard. According to the supervisor, "there is an overhead projector, laptop used by teachers and tablets for students" (Res.1). The experience of the coaches and literacy teachers however suggest that funds are not used to support the technological aspect of the program as many schools lack technological resources and support to facilitate the approach (Res.3, 5,8,9 \&10).

\section{Low Technological Resources:}

Res. 3 stated: "We have one malfunctioned smart board, no allotted APSE rooms. Coaches and literacy teachers find ways to solve space problems." Res. 5 stated that, there is "no current technology to fit the digital space for pathway students." Res.8 outlined that 'there is no projector' and no 'technology room', and Res. 9 said, 'Whiteboard and whiteboard markers' are the only technology we have' while Res. 10 indicated that they had no room to house APSE students and 'no technology lab.'

Hence, in non- traditional schools, there is the issue of spacing as coaches and literacy teachers spent much instructional time searching for rooms or areas where classes for pathway students can be held. According to Res. 7, 'while some schools have a literacy lab that is manly print rich', 'It still does not have the technological facilities to drive the program' (Res. 2).

One serious problem detected is that several of these schools have low to no internet access. This leaves students in these schools at a great disadvantage as they are colossally left behind regarding the digital space and are supposedly highly disadvantaged as they pursue the world of work or further studies which are driven by the digital age (Hampton et al., 2018). The absence of these technologically advanced tools also hinders students' preparation for the fast- growing global digital space (Rodriguez, 2018). 


\section{Low Technological Support}

The study revealed the coaches' inability to compete with the digital competencies required in the fast-growing digital space (Soltan, 2020). According to Res. 1, 'coaches received training each term scheduled by the Ministry of Education, but not enough training was conducted on the use of current technological tools'. Another respondent admitted that 'coaches received workshop held by the Ministry of Education in the utilization of technological tools" (Res 2). The literacy teacher supervised by literacy coaches also agreed that training is received from the Ministry of Education (Res. 3). The other coaches revealed that the experiences were varied with some deficiencies. One coach stated that "coaches do not receive training in current technological tools" (Res. 8) while (Res. 9) agreed that there has been "no training with current technological tools. In summing up the arguments of (Res. $8 \&$ 9), Res. 10 made it clear that regarding current technological tools, "Coaches seldom received training. One over-arching insight that has derived from this conversation among the coaches is that there has been limited technological support for capacity building.

Research Question 3: What is the level of accountability evident in the technology-based program for literacy improvement?

The APSE program needs a high accountability mechanism in that teachers have to engage in careful planning in collaboration with APSE coaches. Lesson plans should be frequently checked and literacy coaches should conduct frequent observations and assessments of teachers during delivery. There should also be formative, intermittent and summative assessment of students. Data derived from the varied assessments should be used to promote students to the next grade level or implement differentiated techniques to improve students' performance.

\section{High Accountability}

The most outstanding feature of the APSE approach is that it has a very high accountability feature which involves the agreement of Supervisors, literacy teachers and coaches. In the APSE program, coaches are evaluated monthly by the regional supervisors and literacy teachers are evaluated by coaches. A supervisor of coaches opined that: "teachers' lesson plans as well as test papers and other modes of assessment are inspected. There are regular classroom observations by coaches" (Res.1). Thus, there are a multiplicity of planning, teaching and training sessions among the coaches and literacy teachers to optimize the improvement of students in literacy. The literacy teacher extrapolated that as a result of these high accountability mechanisms, "students improved in the four areas" (Res. 3). The supervisor of coaches supported this view as she stated that:

"Equal opportunity is provided
to improve in all areas
according to pathway levels
and that students who improve
in the varied areas are placed in
more advanced pathways.
Improvement of students in the
four areas (listening, speaking,
reading and writing) are largely
due to APSE coaches employing
expertise in pedagogical styles
to facilitate the classroom
teachers" (Res. 1).

APSE coaches also agreed that students improved as a result of the varied pedagogy used to support learning (Res.8), but better results could be derived if there were an equal blend between teachers and technology (Hammond, Zielezinski \& Goldman, 2014). The program also had ongoing assessments which were captured for analysis both at the school and ministry levels (Res. 2-10).

Results from evaluations were used to instruct forward planning for the program and for the growing needs of students (Res. 10). The students were also frequently assessed and their improvements on the pathways were tracked by the schools' learning management system (LMS) (Res. 7). Once students showed improvement, they progressed along the respective pathways (Res.9). It was not ascertained whether students managed the transition into the regular curriculum smoothly after the APSE program in grades $7 \& 8$, or whether they grappled at the ninth to eleventh.

\section{Conclusion and Recommendations}

The study came up with a number of conclusions as follows: Regarding teachers' experiences, teachers were in need of specialist support from experts in the field of Social and Behavioral Psychology, Social Work and Counselling to solve mental and emotional challenges that coaches were unable to address. Students in the APSE program were at-risk, predominantly from low- income homes and had behavioral issues that 
affected teachers' ability to effectively offer the program.

With regard to technology in classroom, more technological resources need to be channeled into the non-traditional high schools. The teachers needed to be trained continuously on ICTs and CTE in order to effectively be equipped. Regarding accountability, the program has a plethora of inbuilt features which require a keen sense of accountability at several levels. These accountability mechanisms will help literacy coaches and literacy teachers to determine if students are developing fully along learning pathways and whether or not the program is serving its purpose in optimizing students' success.

Based on the conclusions, the study recommends that policy makers should ensure that all nontraditional high schools accommodate the Guidance Counselling units to tackle the psychological problems of the learners. This task should involve Social Workers, Clinical Psychologists, Behavioral Specialists and Family Therapists.

School authorities should strive to resolve the demand for connectivity. They should ensure that internet and device accessibility become a permanent feature for teachers and students. Additionally, policy makers and curriculum planners should ensure that digital competence becomes a prescribed skill for all teachers.

\section{Reference}

Angus, G.L. (2016, March 24). Government launches apse to help students. Retrieved fromhttps://jis.gov.jm/governmentlaunches -apse-help-students/

Angus, G.L. (2020, November 12). Tablets in schools programme empowering students. Retrieved from https://jis.gov.jm/tablets-inschools-programme-empowering-students /\#: :text=The\%2040\%2C000\%20tablets\%20 are\%20being,Health\%20and\%20Education\% 20(PATH)

APSE and CAP - Alternative pathway to secondary education[factsheet].https://www.moey.go v.jm /sites/default/files/APSE-CAP-Factsh ee t.pdf

Bashith, A., \& Amin, S. (2017). The effect of problembased learning on EFL students' critical thinking skill and learning outcome. Al-Ta Lim Journal, 24(2). https://
journal.Tarbiyahiainib .ac.id/ index. Php /attalim/article/view/271.

Brill, F., Grayson, H., Kuhn, L., \& O'Donnell, S. (2018). What impact does accountability have on curriculum, standards and engagement in education? A Literature Review, NFER.

Charalambas, V., \& Glass, G.V. (2007). Teacher Professional Development and ICT: Strategies and Models. Yearbook of the National Society for the Study of Education. 106(2), 87-102. https://online library .wiley.com/doi/ 10.1111/j.1744- 7984. 2007.00116.x.

Creswell, J. W. (2008). Qualitative Inquiry \& Research Design: Choosing among Five Approaches (3rd ed.). SAGE.

Crossfield, D. \& Bourne, P.A. (2018). An inquiry into Teachers' perception of at-risk students in jamaica : A phenomenological approach. International Journal of Emergency Mental Health and Human Resilience. Vol 20(2) p. 402.

Eshet-Alkalai, Y. (2004). Digital literacy: a conceptual framework for survival skills in the digital era. Journal of Educational Multimedia and Hypermedia, 13(1),93-106.http:// www. openu. ac.il/ Personal_sites/download/ Digital-literacy2004-JEMH.pdf

Fereria, P.J. (2016). Engendering curriculum pedagogy for alternative pathways to secondary education in Jamaica. Caribbean Teaching Scholar, 6 (2016). Retrieved from https://journals. sta.uwi.edu/ojs/ index. php/cts/article/view/819.

Ghavifekr, S., Razak, A. Z.A., Ghani, M.F.A, Ran, N.Y., Meixi, Y., \& Tengyue, Z. (2014). ICT integration in education: Incorporation for teaching and learning improvement. Journal of Educational Technology. Vol. 2(2),pp.2445.

Ghavifekr, S., \& Rosdy, W.A.W. (2015). Teaching and learning with technology: Effectiveness of ICT integration in schools. International Journal of Research in Education and Science (IJRES), 1(2), 175-191. Retrieved from https://files.eric.ed. gov/fulltext /EJ1105224.pdf 
Gill, L., \& Dalgarno, B. (2008). Influences on preservice teachers' preparedness to use ICT's in the classroom. ResearchGate.net.

Gudmundsdottira, G.B., \& Hatlevik, O.E. (2018). Newly qualified teachers' professionaldigital competence: Implications for teacher education. European Journal of Teacher Education, 41(1), pp.1-17.

Hammond, L., Zielezinski, M.B., \& Goldman, S.(2014). Using technology to support at-risk students' learning. Retrieved from https://edpolicy.stanford.edu/sites/default/ files/scope-pub-using-technology-report.pdf

Hampton, K. N., Fernandez, L., Robertson, C. T., \& Bauer, J. M. (2018).Broadband and student performance gaps. Michigan State University. Retrieved from https://doi.org/ 10.25335/BZGY-3V91

Hennessy, S., Deaney, R., \& Ruthven, K. (2005). Emerging teacher strategies for mediating 'technology integrated conversations': a socio-cultural perspective. The Curriculum Journal. Vol. 16(3), pp.265-292.

Hibbert, K. (2020, May 7). Teachers share struggles of distance learning. Retrieved fromhttps://www.jamaicaobserver.com/ne ws/teachers-share-struggles-of-distancelearning_193863?profile $=1470$

Hunter, J. A. (2014, June 13). Non- traditional high school students beating the odds. https: //jis.gov.jm/non-traditional-highschool-students-beating-odds/

Iftakhar, S. (2016). Google Classroom: What Work $s$ and How? Journal of Education and Social Sciences, 3(Feb.). ISSN 2289-9855. Retrieved from https://www.jesoc.com/wp-content/ uploads/2016/03/KC3_35.pdf

Irving, K.E. (2006). The Impact of Technology on the 21st Century Classroom/Teaching Science in the 21century classroom. Retrieved from https://learningcenter.nsta.org/ resource/ ?id=10. 2505/9780873552691.1.

Ivy, J. (2017) .Use of technology in the classroom/ file:///D:/Use\%20of\%20Technology\% 20In \%20The \%20Classroom\%20-\%20Use\% 20of \%20Technology\%20lvy. html/ techucation/ educationtechnology/september 26,Jamaica

National Development Plan. (2009). Vision 2030 Education Final Draft Sector Plan.
Kavalier, B.R., \& Flannigan, S.L. (2006). Connecting the dots: Literacy of the $21^{\text {st }}$ century, Educause Quarterly. Retrieved from https://er.educause.edu/articles/ 2006/1 /connecting-the-digital-dots-literacy-of-the21st-century

Korkmaz, G., \& Kalayci, N. (2019). Theoretical foundations of project- based curricula in higher education. Cukurova University Faculty of Education Journal, 48(1), 236-27. https:// scholar.google.com/citations?user=piQdZW cAAAAJ\&hl=tr

Kuckartz, U, (2014). Qualitative text analysis: A guide to methods, practice and using software. Sage.

Larose, S., \& Tarabulsy, G. M. (2014). Academically at-risk students In David L. DuBois and Michael J. Karcher (Eds). Handbook of Youth Mentoring (2nd edition). New York : Sage Publications.

Lewis, H. (2016, January 7). Streamlining education for success. Retrieved from https:// www.google.com/search?q=5.+Lewis $\% 2 \mathrm{C}+\mathrm{H}$ .+(2016\%2C+January+7).\%E2\%80\%98Stream +Lining+Educatio n+for+ Succe ss\%E2\% $80 \% 99$.

Matthews, L. (2018, March 27). Education system not designed for accountability. Retrieved from https://www.jama icaobserve r.com/opinion/education-system-not designe d-for-accountability_12 8239?pr ofile $=1096$

Mignott, D. (2020, February 11). APSE needs suppor t. Retrieved from http://jamaica- gleaner.co $\mathrm{m} /$ article/commentary/2 0200211/dania hmignott-apse-needs-support

Ministry of Education, Youth and Information, (2017). APSE Curriculum - Communication skills and the use of technology -Grade 7-9, Jamaica. Retrieved from https:// moey. Go v.jm/curricula

Ministry of Education, Youth and Information, Educational Services Division. (2016, May). Alternative Pathway to Secondary Education (APSE) Procedural Guide, Jamaica (see appendix)

Morgan, H.(2012, October 3). Our men are killing us. The Jamaica Observer. Retrieved 
fromhttp://www.jamaicaobserver.com/ columns/Our-men-are-killing-us_12671462

Moustakas, C. E. (1990). Heuristic research: Design, methodology, and applications. Sage Publications, Inc.

Neubauer, B.E., Witkop, C.T. \& Varpio, L. (2019). How phenomenology can help us learnfrom the experiences of others. Perspectives on Medical Education, 8, 90-97. https://doi.org/ 10.1007/s 40037-019-05092.

Purdue University. (2020). The Evolution of Technology in the Classroom. https:// online.purdue.edu/blog/educationn/evoluti on $\mathrm{n}$ n-technology-classroom

Rodriguez, L. (2018). Tech based education holds back low-income students: Reporthttps://www.globalcitizen.org/en/co ntent/low-income-students-technologyeducation/

Ruales, S.T.P (2012). ICT Integration in teacher education institutions. The Mindanao Forum,XXIV(2).https://www.researchgate.n e t/publicat ion/ 272793227

Savery, J. R. (2006). Overview of problem-based learning: Definitions and distinctions.Interdis ciplinary Journal of Problem-based Learning, 1(1),9-20. Retrieved from https://eri c.ed.gov/?id= EJ1055411.

Soltan, L. (2020). Digital divide: The technology gap between the rich and poor. Retrieved from http://www.digitalresponsibility.org/digital- divide-the-technology-gap-between-richand-poor.

Spires, H. S., Paul, C.M. \& Kerkhoff, S. (2017). Digital literacy for the 21st century. Encylopedia of Information Science and Technology $\left(4^{\text {th }}\right.$ ed.). IGI Global.https:// wwwdoi:1 0.4018/978-1-5225-7659-4.ch002.

Sweeney, A. (2019, April 7). Promoting stem education and literacy in Jamaica. The Sunday Gleaner. Retrieved from http://jamaica-gleaner.com/article/art-leisu $\mathrm{re} / 20190407$ /promot ingstemeducation-a nd- literacy-jamaica

Tondeur, J., Braak, J.V., Ertmer, P.A., \& Leftwich, A.O.(2016). Understanding the relationship between teachers' pedagogical beliefs and technology use in education: A systematic review of qualitative evidence. Educational Technology Research and Development 65(3)

UNESCO (2019). Vision 2030. Retrieved from https://en.unesco.org/news/repositioningliteracy-meet-2030-education-agendatargets.

USA Department of Education. (2017). National Educational Technology Plan, 2020. Retrieved from https://tech.ed.gov/netp/

Venkatraman, S., DeSouza-Daw, T., \& Kaspi, S. (2018). Improving employment outcomes of career and technical education students/School of Engineering, Construction and Design. Prahran Campus, Australia. Retrieved from https://www.doi/10.1108/HESWBL-012018-0003/full/pdf 